\title{
Front Matter: Volume 11733
}

, "Front Matter: Volume 11733," Proc. SPIE 11733, Geospatial Informatics XI, 1173301 (4 May 2021); doi: 10.1117/12.2598610

SPIE. Event: SPIE Defense + Commercial Sensing, 2021, Online Only 


\title{
PROCEEDINGS OF SPIE
}

\section{Geospatial Informatics XI}

\author{
Kannappan Palaniappan \\ Gunasekaran Seetharaman \\ Joshua D. Harguess \\ Editors
}

12-16 April 2021

Online Only, United States

Sponsored and Published by

SPIE 
The papers in this volume were part of the technical conference cited on the cover and title page. Papers were selected and subject to review by the editors and conference program committee. Some conference presentations may not be available for publication. Additional papers and presentation recordings may be available online in the SPIE Digital Library at SPIEDigitalLibrary.org.

The papers reflect the work and thoughts of the authors and are published herein as submitted. The publisher is not responsible for the validity of the information or for any outcomes resulting from reliance thereon.

Please use the following format to cite material from these proceedings:

Author(s), "Title of Paper," in Geospatial Informatics XI, edited by Kannappan Palaniappan, Gunasekaran Seetharaman, Joshua D. Harguess, Proc. of SPIE 11733, Seven-digit Article CID Number (DD/MM/YYYY); (DOI URL).

ISSN: 0277-786X

ISSN: 1996-756X (electronic)

ISBN: 9781510643031

ISBN: 9781510643048 (electronic)

Published by

SPIE

P.O. Box 10, Bellingham, Washington 98227-0010 USA

Telephone +1 3606763290 (Pacific Time)

SPIE.org

Copyright @ 2021 Society of Photo-Optical Instrumentation Engineers (SPIE).

Copying of material in this book for internal or personal use, or for the internal or personal use of specific clients, beyond the fair use provisions granted by the U.S. Copyright Law is authorized by SPIE subject to payment of fees. To obtain permission to use and share articles in this volume, visit Copyright Clearance Center at copyright.com. Other copying for republication, resale, advertising or promotion, or any form of systematic or multiple reproduction of any material in this book is prohibited except with permission in writing from the publisher.

Printed in the United States of America by Curran Associates, Inc., under license from SPIE.

Publication of record for individual papers is online in the SPIE Digital Library.

\section{SPIE. DIGITAL}

Paper Numbering: A unique citation identifier (CID) number is assigned to each article in the Proceedings of SPIE at the time of publication. Utilization of CIDs allows articles to be fully citable as soon as they are published online, and connects the same identifier to all online and print versions of the publication. SPIE uses a seven-digit CID article numbering system structured as follows:

- The first five digits correspond to the SPIE volume number.

- The last two digits indicate publication order within the volume using a Base 36 numbering system employing both numerals and letters. These two-number sets start with 00, 01, 02, 03, 04, 05, 06, 07, 08, 09, 0A, OB ... 0Z, followed by 10-1Z, 20-2Z, etc. The CID Number appears on each page of the manuscript. 


\section{Contents}

\section{GEOSPATIAL INFORMATICS APPLICATIONS}

1173305 Synthetic imagery for spatial resolution selection in maritime remote sensing [11733-3]

$1173306 \quad$ Using deep perceptual embeddings as a quality metric for synthetic imagery [11733-4]

GEOSPATIAL DATA MINING, ALGORITHMS, AND VISUALIZATION

$117330 \mathrm{~A} \quad$ Image translation to enhance IR2VIS image registration [1 1733-8]

11733 OB Semi-supervised exemplar learning for object detection in aerial imagery [1 1733-9]

11733 OC Targeted adversarial discriminative domain adaptation [11733-10]

\section{VIDEO ANALYTICS}

11733 OD Multi-modal dataset generation using domain randomization for object detection [11733-11]

11733 OF The vulnerability of UAVs: an adversarial machine learning perspective [11733-13]

11733 OG Automating situational reporting [11733-14]

\section{ENVIRONMENTAL AND DISASTER ANALYTICS}

$11733 \mathrm{OH} \quad$ Water distribution network function and centrality [1 1733-15]

11733 Ol Forest fire spread prediction using deep learning [1 1733-16]

11733 OJ Critical node analysis (CNA) in power grids under enhanced restoration options [11733-17]

11733 OM Quantifying methane emissions in Delaware from field-based mid-IR sensors and satellite observations [1 1733-20]

\section{POSTER SESSION}

11733 ON Public health precautions for preventing malaria using environmental data [11733-21] 
Proc. of SPIE Vol. 11733 1173301-4 Downloaded From: https://www.spiedigitallibrary.org/conference-proceedings-of-spie on 26 Apr 2023
Terms of Use: https://www.spiedigitallibrary.org/terms-of-use 